\title{
Gender Differences in The Attribution of Creative Thinking: Experimental Evidence using STEM-based E-Module
}

\author{
Lilit Rusyati ${ }^{1}$, Diana Rochintaniawati ${ }^{2}$, Rika R. Agustin ${ }^{3}$, Yayan Sanjaya ${ }^{4}$, Ivaldy G. Deandra ${ }^{5}$ \\ \{lilitrusyati@upi.edu ${ }^{1}$ \}
}

International Program on Science Education, Universitas Pendidikan Indonesia, Jl. Dr. Setiabudi No. 229, Bandung 40154, Indonesia ${ }^{1,2,3,4,5}$

\begin{abstract}
The need for developing competent human resources on 21st Century Skills nowadays are become an issue. In this research, STEM-based E-Module can be an option. Investigate the effect of implementing STEM-based E-Module, investigate the differences between the female and male group on their creative thinking, and determine students' impression on STEM-based E-Module are the objectives. The pre-experiment method with one group pre-test and post-test was conducted through a research subject of 8th-grade students at a private school in Bandung that taken from a purposive sampling. The result stated that there is a significant difference between the post-test of Verbal TTCT and the minimum criteria of mastery learning that has been decided as standard (i.e., 65). In differentiating between the female and male groups on their creative thinking, an independent t-test was conducted. But there are no significant differences between the female group and the male group on their creative thinking.
\end{abstract}

Keywords: STEM-based e-module, students' creative thinking, gender, oxygen for life.

\section{Introduction}

Science and technology nowadays are rapidly developed as the world enters the globalization era. It makes the demand in the sector of science, technology, and their application is very high. Technology is everywhere, for example how to examine diseases, how to overcome the change of climate and weather, or even how it is the most advanced airport screening technology [1]. This development is also impacting the needs of education quality improvement to create proficient human resources in order to complete one type of skill, which is 21 st-Century skills. These 21 st-Century skills are the abilities to understand something, have competencies to work, and creating resolutions in this era. Complex thinking and communication skills are categorized as 21 st-Century skills, that being emphasized in the teaching-learning process, especially in teaching science [2].

The needs of developing competent human resources on 21st-Century skills also happen in Indonesia. There are some challenges that faced by Indonesia in the future such as globalization, environmental problem, development of informational technology, convergence of science and technology, science-based economy, rising of creative and cultural industry, shift of economic power, effect of science and technology, quality and transformation of education, and also TIMSS and PISA materials. The 21st-Century skills development is one of the solutions to face the challenge such as communication skills, critical thinking, and moral- 
based problem-solving. Even Indonesia is being one of the most reputable countries in its development in many sectors especially in science and technology, but there is also another dissatisfactory fact indicated that Indonesia has low-skilled and cheap manpower.

This fact is becoming a challenge for the educational sector in Indonesia. The fierce competition in this century depends on how education creates a human that have creative thinking skill, flexibility in solving a problem, collaboration, and innovation competencies as stated in the 21st-Century skills. STEM (Science, Technology, Engineering, and Mathematics) education can be proposed as the solution. This interdisciplinary study will make students figure out the identification, application, and integration of those four disciplines to determine the appropriate solution of the real-life problem. When STEM education reinforced more, students will be able to gain understanding and skills for their future [3].

The compulsory teaching STEM subject may lead to important dealing of classroom management, one of the main examples is the provision of creative, innovative, and interdisciplinary resources [4]. In this digital era, there is a possibility to develop a creative and innovative learning media of science, one of the examples is an Electronic-book (E-book). The E-book is a digitalized textbook that integrating the use of multimedia to make interesting learning [5]. The use of science E-book has proven that it develops collaboration and problem-solving skills of the students in the teaching-learning process [6].

\section{Method}

The research method that was used in this research is pre-experiment. Pre-experiment is a type of research that using a single subject to determine causal relationships between the independent variable and dependent variables without any extraneous variables. Extraneous variables are any variables that may affect the outcome of the research [7]. This method is appropriate with the purpose of the research which investigated the effect of STEM-based EModule to students' creative thinking in learning in Oxygen for Life topic. Because it can determine the changes independent variable but not due to extraneous factors. The preexperimental method may able to approach the true experimental method [8].

The research design that was used in this research is one group pre-test and post-test, which means that the researcher only takes an experimental group to measure the group's dependent variable $\left(\mathrm{O}_{1}\right)$, which usually called a pre-test. The pre-test was given to the subjects using the instrument of the Torrance Test of Creative Thinking. Then, the next step was giving an experimental manipulation (X), which is learning with STEM-based E-Module, before conducting the TTCT post-test $\left(\mathrm{O}_{2}\right)$ [7].

The research was taken in a private bilingual junior high school in Bandung. The school uses bilingual English and Bahasa Indonesia in their learning activity of science in order to understand any international learning sources. The curriculum of the Junior High School is the National Curriculum of 2013. The population in this research was the $8^{\text {th }}$-grade students of the private bilingual junior high school in Bandung. The samples were $8^{\text {th }}$-grade students from one class. The sampling technique that is used is convenience sampling which is a selection of subjects selected by the willingness researcher and its available to be studied [8]. This technique was used because of the topics of E-Module that has been developed, which is Oxygen for Life topic, is suited for the $8^{\text {th }}$-grade students.

The research instrument is a tool to measure, observe, or collect data quantitatively. The research instrument that is used in this research consists of two types, namely Verbal TCTT 
for measuring students' creative thinking and questionnaire for measuring students' impressions. The Verbal TCTT was developed to measure students' creative thinking in Oxygen for Life topic. This test was given to the students in the pre-test, which was before any implementation of STEM-based E-Module, and post-test which was after the treatment given to them. The test fulfills all subjects of Verbal TTCT, which are asking questions, guessing causes, guessing consequences, product improvement, unusual uses, and just suppose. Those instruments measure three aspects that included in the creative thinking test, which are fluency, flexibility, and originality.

\section{Results and Discussion}

Verbal TTCT was given to the subject of the research to determine their creative thinking. The instrument was distributed twice, for pre-test and post-test, it was using a concept that is tested was the same, Oxygen for Life. This Verbal TTCT was scored by an assessment rubric of Verbal TTCT that has been validated by expert judgment. Then, the scores that have been obtained as shown in Table 1 from all of the research subjects were analyzed to determine the normality of items, homogeneity test of items, also test the hypothesis of the research. The SPSS version of 24 software was used to analyze the instrument that consists of eleven questions in the form of an essay.

Table 1. Descriptive statistics of verbal TTCT pre-test and post-test scores.

\begin{tabular}{lcc}
\hline \multicolumn{1}{c}{ Component } & Pre-Test & Post-Test \\
\hline \multicolumn{1}{c}{$\mathrm{N}$} & 23 & 23 \\
Average score & 35.09 & 74.27 \\
Standard Deviation & 9.48 & 10.27 \\
Maximum Score & 53.54 & 94.95 \\
Minimum Score & 21.21 & 53.54 \\
Average gain score & \multicolumn{2}{c}{ 0.603 (medium) } \\
Average & \multicolumn{2}{|}{} \\
Normalized gain score & Shapiro-Wilk Normality Test \\
Significant & 0.276 & 0.854 \\
(sig. A =0.05) & \multicolumn{2}{|}{ Normally distributed } \\
Conclusion
\end{tabular}

The improvement of students' creative thinking a be indicated by the average gain score which is 39.18. The average normalized gain score is 0.603 , it means that the average normalized gain score is at a medium level. It is indicating that the creative thinking of students is developed. In learning the complicated science concept, E-module helps students to be more understanding of the concept itself. In this case, students learn about Oxygen for Life by using STEM-based E-Module. Students gain a higher score because of the help of EModule so that the concept of Oxygen for Life is easy to be understood by students. E-Module as a virtual learning media also can be used to improve students' outcomes in learning science topics.

The differences between the female and male groups in their creative thinking based on the post-test Verbal TCTT can be determined by using independents sample T-test. Another 
requirement needs to fulfill, which is homogeneity. By using Levene's test of homogeneity, it can be determined that the data is homogeneous or not as shown in Table 2.

Table 2. Verbal TCTT score between the female and male groups.

\begin{tabular}{|c|c|c|}
\hline Component & Female & Male \\
\hline $\mathrm{N}$ & 14 & 9 \\
\hline Average score & 75.11 & 72.95 \\
\hline Standard Deviation & 10.42 & 11.04 \\
\hline \multicolumn{3}{|c|}{ Levene's Test for Equality of Variance } \\
\hline $\begin{array}{l}\text { Significant } \\
\text { (sig. } \alpha=0.05 \text { ) }\end{array}$ & \multicolumn{2}{|c|}{0.752} \\
\hline Conclusion & \multicolumn{2}{|c|}{ Homogenous } \\
\hline \multicolumn{3}{|c|}{ Hypothesis Test } \\
\hline $\begin{array}{l}\text { Signification } \\
(\text { sig. } \alpha=0.05)\end{array}$ & \multicolumn{2}{|c|}{$\begin{array}{l}\text { Independent sample T-test } \\
\quad \text { Sig. } 2 \text {-tailed }=0.641\end{array}$} \\
\hline Conclusion & \multicolumn{2}{|c|}{$\begin{array}{c}\mathrm{H}_{0} \text { accepted, there is no significant difference } \\
\text { between male and female group }\end{array}$} \\
\hline
\end{tabular}

The sig. 2-tailed value is 0.641 , far too high than the significance which is 0.05 . It can be concluded that there is no significant difference between female and male groups on their creative thinking after the implementation of STEM-based E-Module. This is in line with research that there is no difference between students' creative thinking between female and male because of the life experience are the same (Hong, Peng \& Wu, 2013). Because creativity is developed by the situation, the factors of gender are limited in developing creative thinking [9]. As the female and male group has been given the same treatment so that they gain the same score of creative thinking. If the treatment is the same, actually the learning strategy related to developing creative thinking is different between males and females [10].

Students' impression of STEM-based E-Module in this research is determined by using a questionnaire using4-Likert scale. There are five aspects that were determined in the questionnaire of students' impressions, which are program aspect (57.37/enough), creative thinking aspect (59.4/enough), content aspect (56.25/lack), general impression aspect (51.57/lack), and STEM project-based activity aspect (58/enough). STEM-based E-Module may encourage the students in the self-directed learning of students, as they decide the best of time, place and strategy of learning [11]. Anyone, anytime, anywhere, science learning can be done. Science E-Module that is used especially by the students helps to develop a deeper understanding of grade-level science concepts [6].

\section{Conclusion}

The implementation of STEM-based E-Module that can fulfill almost all of the activities based on the lesson plan (93\%). The using of STEM-based E-Module gives an improvement of students' creative thinking in learning Oxygen for Life topic. But there are no significant differences between the female group and the male group post-test, indicating that the teaching-learning process can be accepted by both of them. Students enjoyed the learning with E-module, such as the layout of text, picture, and video of the E-module. 


\section{References}

[1] Marrero, M. E., Gunning, A. M., and Germain-Williams, T.: What is STEM education?. Global Education Review. 1(4) 2014)

[2] Saavedra, A. R., and Opfer, V. D.: Learning 21st-century skills requires 21st-century teaching. Phi Delta Kappan, 94(2), 8-13 (2012)

[3] Khalil, N., and Osman, K.: STEM-21CS module: Fostering 21st century skills through integrated STEM. K-12 STEM Education, 3(3), pp. 225-233 (2017)

[4] Kurup, P. M., Brown, M., Powell, G., and Li, X.: Future primary teachers' beliefs, understandings and intentions to teach STEM. Journal of Education. 5. pp. 161-178 (2017)

[5] Lai, C. S.: Integrating E-Books into Science Teaching by Preservice Elementary School Teachers. Journal of Education in Science, Environment and Health. 2(1). pp. 57-66 (2016)

[6] Encheff, D.: Creating a science e-book with fifth grade students. TechTrends. 57(6). pp. 61-72 (2013)

[7] Creswell, J. W.: Educational Research: Planning, Conducting and Evaluating Quantitative and Qualitative Research. Boston: Pearson Education (2012)

[8] Cohen, L., Manion, L., and Morrison, K.: Research methods in education. Routledge (2002)

[9] Kemmelmeier, M., and Walton, A. P. :Creativity in men and women: Threat, other-interest, and self-assessment. Creativity Research Journal, 28(1), pp. 78-88 (2016)

[10] Matud, M. P., Rodríguez, C., \& Grande, J.: Gender differences in creative thinking. Personality and individual differences. 43(5). pp. 1137-1147 (2007)

[11] Dobler, E.: e-Textbooks: A Personalized Learning Experience or a Digital Distraction?. Journal of adolescent \& adult literacy. 58(6). pp. 482-491 (2015) 